\title{
Kum Zeminlerdeki Kazıklı Radye Temellerin Optimum Kazık Aralığının Deneysel Olarak İncelenmesi
}

\author{
Bayram ATEŞ ${ }^{1}$ \\ Erol ŞADOĞLU ${ }^{2}$
}

ÖZ

Kazıklı temeller, yapı yüklerinin yüzeysel temellerle güvenle taşıtılamadığı durumlarda kullanılmaktadır. Kazıklı radye temeller, kazık ve radyenin yük taşıma kapasitelerini birleştiren bir temel sistemi olması sebebiyle son yıllarda ön plana çıkmıştır. Bu sebeple söz konusu temel sistemlerinin güvenilir ve ekonomik tasarımı için kapsamlı teorik ve deneysel çalışmalar yapılmaktadır. Bu çalışmada, kum zemin içerisinde yer alan kazıklı radye temellerin tasarım parametrelerinin etkileri (kazıklar arası mesafe, kazık çapı, kazık uzunluğu ve rölatif sıkılık, vb.) deneysel olarak araştırılmıştır. Laboratuvar deneylerinde, çap1 20 ve 30 mm, uzunluğu 200 ve 300 mm olan model kompozit (çelik ve beton) kazıklar kullanılmıştır. Plan boyutları 160x160 mm, 240x240 mm ve kalınlığ1 $6 \mathrm{~mm}$ olan model radyeler, çelik plakadan imal edilmiştir. Farklı tasarım parametrelerine sahip model kazıklı radye temeller test edilmiştir. Deney sonuçlarından, kazıklı radye temellerde kazıklar arası mesafe arttıkça taşıma gücünün bir sınır değer kadar arttığı ve kazıklar arası optimum mesafenin 4D olduğu belirlenmiştir. Temel mühendisliği uygulamalarında kullanılmak üzere tasarım parametreleri önerilmiştir.

Anahtar Kelimeler: Kazıklı radye temel, kazık tasarım parametreleri, optimum kazık aralığ1.

\section{ABSTRACT \\ Experimental Investigation of Optimum Piles Spacing for Piled Raft Foundation in Sandy Soils}

Piled foundations are used in the cases where the structural loads cannot be carried safely with the shallow foundations. Piled raft foundation has become a prominent foundation system in recent years due to that it combines load bearing capacities of piles and raft.

\footnotetext{
Not: Bu yazı

- Yayın Kurulu'na 10 Kasım 2019 günü ulaşmıştır. 17 Nisan 2020 günü yayımlanmak üzere kabul edilmiştir.

- 31 Mart 2021 gününe kadar tartışmaya açıktır.

- https://doi.org/10.18400/tekderg.644885

1 Trabzon Sosyal Güvenlik Kurumu, İnşaat-Emlak Şube Müd., Trabzon - bayramates61@hotmail.com https://orcid.org/0000-0002-1251-7053

2 Karadeniz Teknik Üniversitesi, İnşaat Mühendisliği Bölümü, Trabzon - erolsadoglu@hotmail.com https://orcid.org/0000-0001-2345-6789
} 
Therefore, comprehensive analytical and experimental studies have been carried out for reliable and economic design of piled raft foundations. In this study, the effects of design parameters of piled raft foundations in sand (pile spacing, pile diameter, pile length and relative density etc.) have been investigated experimentally. In the laboratory tests, model composite (steel and concrete) piles with diameters of $20,30 \mathrm{~mm}$ and lengths of 200,300 $\mathrm{mm}$ were used.The raft was made of steel plate with plan dimensions of $160 \times 160,240 \times 240$ $\mathrm{mm}$ and a thickness of $6 \mathrm{~mm}$. The model piled raft foundations with different design parameters were tested. From the tests results, as the pile spacing getting larger, the bearing capacities of the model pile raft foundation increased up to a limit value and the optimum distance between the piles was determined to be 4D. Some design parameters are suggested for use in foundation engineering applications.

Keywords: Piled raft foundation, design parameters of pile, optimum pile spacing.

\section{GİRiş}

Kentleşme oranının ve insan nüfusunun hızla artması ile çok katlı yüksek yapıların, yumuşak ve gevşek zemin (geoteknik özellikleri zayıf zeminler) koşullarında da planlanıp inşa edilmeleri zorunlu hale gelmiştir. Kompleks yapıya ait temellerin, yapıdan gelen yükleri güvenle taşımasının yanı sıra talep edilen oturma koşulunu da sağlaması gerekmektedir. Ayrıca yapılan temel tasarımının ekonomik olması geoteknik mühendislerinin arzusudur. Bazı durumlarda zemin tabakaları taşıma gücü açısından yeterli olsa bile, izin verilebilir oturmaların aşılması ve farklı oturmaları engellemek için radye temellerin altına kazıklar inşaa edilmekte ve oturmaların önlenmesinde bu kazıklar önemli rol oynamaktadır. Zayıf zeminler üzerinde inşaat yapılmasının zorunlu olduğu durumlarda, kazıklı ya da radye temel sistemleri sıklıkla kullanılmaktadır. Kazıklı radye temel inşası, sıkça karşılaştığımız ve yapı yüklerinin zemine aktarılmasında hem radyenin hem de kazıkların kullanıldığı bir temel çeşididir. Kazıklı radye temel uygulamaları son yıllarda birçok çalışmaya konu olmuştur. Bu tür temellerin; düşey, yatay ve dinamik yükler altındaki davranışları çeşitli yönleri ile araştırılmaktadır. Kazıklar, oturma ve farklı oturmaların en aza indirilmesini, yüzeysel temelin taşıma gücünün arttırılmasını, radyede oluşabilecek momentlerin kontrol edilmesini sağlar. Analitik yönden, kazıklı radye temeller en karmaşık temel sistemlerinden biridir.

Çeşitli zemin türlerinde optimum kazık aralığının tespiti için çeşitli araştırmacılar tarafından laboratuvarlarda bazı deneysel çalışmalar yürütülmüştür. Kishida ve diğ. [1], kazık sayısı, kazık aralığı ve eksantrik yükleme gibi bazı parametreleri araştırabilmek amacıyla model deneyler gerçekleştirmişlerdir. $1.27 \mathrm{~cm}$ çap ve $27.83 \mathrm{~cm}$ uzunluğa sahip 12 kazık kullanılarak yapılan model deneylerde kayma mukavemeti açıs $35^{\circ}$ ve $43^{0}$ olan iki farklı sıkılıkta kum zemin kullanmışlardır. Sonuçta, serbest başlıklı kazık gruplarında, gevşek kum zemin durumunda, kazıklar arası mesafe azaldıkça, taşıma gücünün arttığı ve en yüksek taşıma gücünün kazık çapının 2 katı kazıklar arası mesafede meydana geldiği; sıkı kum zemin durumunda, kazıklar arası mesafe azaldıkça, taşıma gücünün de genleşim etkisinden dolayı azaldığ belirtilmiştir. Tutulu başlıklı kazık gruplarında ise, hem gevşek hem de sıkı zeminde artan kazık aralığına bağlı olarak taşıma gücünün arttığı ve 3D kazık aralığında kazıklarda grup etkisinin kalktığı ifade edilmiştir. Cooke [2], Whitaker [3]'in deney sonuçlarını laboratuvar ortamında yapmış olduğu deneylerle karşılaştırmış ve Whitaker [3]'in sonuçlarını doğrulamıştır. Ayrıca, deneylerinde kazıkların oturmaya etkisini de araştırmıştır. 
Sonuçta, oturmaları azaltmak amacıyla kullanılan kazıkların sayısının arttırılmasının, 4D'den ( $\mathrm{D}=$ kazık çapı) daha küçük kazık aralık değerlerinden sonra kayda değer bir fayda getirmediğini ifade etmiştir. Sönmez [4], alt tabakadaki kil tabakasından dolayı oturan orta sıkılıktaki kumdaki kazık gruplarının negatif çevre sürtünmesini araştırmıştır. $30 \mathrm{~mm}$ x $30 \mathrm{~mm}$ kesitindeki ahşap kazıklar kuma 2D, 3D, 4D ve 5,5D mesafeleri ile grup olarak çakılmıştır. Kumdaki rölatif sıkılık değeri, yağmurlama ve sıkıştırma yöntemleri kullanılarak \% 67 civarında bulunmuştur. $1000 \mathrm{~mm}$ çapındaki, $690 \mathrm{~mm}$ yüksekliğindeki tanka hava basıncı verilmiş ve kazık gruplarını içeren kumu yüklemek, için 1,24 m çapında esneyebilir kauçuk plaka kullanılmıştır. Kum yüzeyindeki oturmalar, grup içindeki ve dışındaki komparatör saatleri ile ölçülmüştür. Kazıklar arası mesafeler 3D ve daha az olduğu zaman, kohezyonsuz malzeme ve kazıkların blok olarak davrandığı ve grup içindeki oturmaların grup dışındaki oturmalara göre daha az olduğu gözlenmiştir. Kazık arası mesafeler 4D den fazla olduğu zaman grup içinde ve dişında benzer oturmalar ölçülmüştür. Sonuç olarak orta sıkılıktaki kumda, oturmadaki grup davranışının 3D ve 4D kazık mesafeleri arasında başladığı bulunmuştur. Ayrıca Tomlinson [5], optimum kazık aralığının 4D olduğunu ifade etmiştir. Farklı zemin türlerinde optimum kazık aralığının tespiti için çeşitli araştırmacılar tarafından arazide deneysel çalışmalar yürütülmüştür. York ve Leahy [6], New Jersey'deki Newark Uluslararası Havalimanının güçlendirilmesinde boru kazıklar kullanmışlardır. Yaptıkları çalışmada, kazıklara gelen yükün kaldırılması sonucunda meydana gelen kabarmaları incelemişlerdir. Yapılan çalışma sonucunda, çok geniş kazık gruplarında bu kabarmaların daha fazla olduğunu ifade etmişlerdir. Ayrıca, kabarma miktarının, kazık grubundaki kazıkların birbirine olan mesafesi azaldıkça arttığını ve kabarmanın kazık grubunun merkezindeki kazıklarda daha fazla olduğunu belirtmişlerdir. Ayrıca, çok geniş kazık grubu inşası durumunda, kazık üzerindeki radyede dilatasyon derzinin bırakılması gerektiğini ve imal edilecek olan kazıkların mesafesinin en az 12 kazık çapı kadar olması gerektiğini, meydana gelecek olan kabarma miktarının en ekonomik şekilde en aza indirilmesi için kazık grubu şeklinin $\mathrm{H}$ şeklinde olması gerektiğini tavsiye etmişlerdir. Ismael [7], 5 kazıktan oluşan iki farklı kazık grubunda kazık aralığı ve kazık çapının taşıma gücüne etkisini araştırabilmek amacıyla arazi deneyleri gerçekleştirmişlerdir. Deneylerin gerçekleştirildiği arazideki zemin hafif çimentolaşmış kum zemin olarak ifade edilmektedir. Yapılan değerlendirmeler sonucunda, kazık çapının 2-3 katından daha az aralıklarda kazık grubunun oturmasının tekil kazıktan daha fazla olduğu, elastik oturmanın ise, kazık grubunun genişliği ile arttığı ifade edilmiş olup; uygun değer kazık aralığının 2-3D olduğu belirtilmiştir. Elsamee [8], yaptığı deneysel ve nümerik çalışmalarda kum zeminde farklı kazık aralıklarına sahip kazıklı temelleri düşey olarak yükleyerek, optimum kazık aralığının 4D olduğunu belirtmiştir.

Günümüzde kazıklı temellerin imalatı ve uygulanması için bazı ülkeler tarafından şartnameler oluşturulmuştur. Grup içindeki (dairesel kesitli sürtünme kazıkları) kazıklar arası mesafe için Amerikan şartnamesi 2D, İngiliz şartnamesi 3D, Alman şartnamesi 4D, Japon şartnamesi 2,5D, İsveç şartnamesi ise kazık uzunluğuna bağlı olarak 3-5D önermektedir [9, 10]. Kazıklı radye temellerin en önemli tasarım değişkenlerinden biri optimum kazık aralığı olup, kazıklı radye temellerin optimum kazık aralığı ile ilgili sınırlı sayıda deneysel ve teorik çalışma bulunmaktadır. Bu çalışma kapsamında, farklı rölatif sıkılığa sahip kum zeminde, farklı geometrik özelliklerde model radye ve model kazıklı radye temel düşey doğrultuda yüklenerek optimum kazık aralığı tespit edilmeye çalışılmıştır. Böylece rölatif sıkılığın, kazık çapının ve kazık boyunun optimum kazık aralığı üzerindeki etkilerinin belirlenmesi hedeflenmiştir. 


\section{DENEYSEL ÇALIŞMALAR}

Kazıklı radye temel davranışını arazi deneyleri ile modellemek yüksek bir maliyet gerektirir. $\mathrm{Bu}$ nedenle söz konusu temelin davranışı konusundaki parametrik çalışmalar çoğunlukla model laboratuvar deneyleri ile yapılabilmektedir. Bu çalışmada; kum zeminde düşey yüklü kazıklı radye temellerin, farklı rölatif sıkılıkta optimum kazıklar arası mesafesini $\left(\mathrm{S}_{\mathrm{opt}}\right)$ gözlemlemek için bir deney düzeneği yapılmıştır. Deney düzeneği; deney tankı, model radye temel, model kazıklar, yükleme düzeneği, lineer değişken diferansiyel transformatörler (LVDT), yük hücresi, kum yüzeyini düzleme aleti ve kum ana parçalarından oluşmaktadır. Deney düzeneğinin şeması Şekil 1'de görülmektedir. Bunlara ilaveten, deneylerde kumun istenilen rölatif sıkılıkta sıkıştırılması için titreşimli sıkıştırma cihazı kullanılmıştır. Deneyler, K.T.Ü. İnşaat Mühendisliği Bölümünün Geoteknik Laboratuvarında gerçekleştirilmiş olup, laboratuvarda bulunan üç eksenli deney aletinin presi, deformasyon ölçüm saatleri, bilgisayar ile dijital fotoğraf makinesi kullanılmıştır. Deney tankının içi bir küp prizması olup, uzunluğu $1.00 \mathrm{~m}$, genişliği $1.00 \mathrm{~m}$ ve yüksekliği 1.00 metredir. Seçilen tank boyutları, sınır etkisi oluşmayacak şekilde literatür ve sayısal analiz sonuçları dikkate alınarak hazırlanmıştır. Yükleme esnasında sınır etkisini kontrol etmek amacıyla sonlu elemanlar yöntemi ile yapılan analizlerin yanı sıra deformasyon saatleri yardımıyla hem deney tankı hem de kum zeminde ki hareket gözlenmiştir. Kasanın iskeleti çelik profillerden imal edilmiştir. Deney esnasında rijitliği sağlamak için tanka belli noktalardan kaynak yapılmış olup; çelik kuşaklar ve bulonlar ile sağlamlaştırılmıştır. Deneyler esnasında, zemini tank içine daha kolay yerleştirebilmek ve istenilen rölatif sıkılıkları sağlayabilmek için, tankın iç yüzeyleri beşer $\mathrm{cm}$ aralıklarla çizilerek, kum zeminin tabakalar halinde yerleşimine olanak sağlanmıştır. Deney tankına üç eksenli aletin presini bağlamak için çelik kiriş monte edilmiştir.

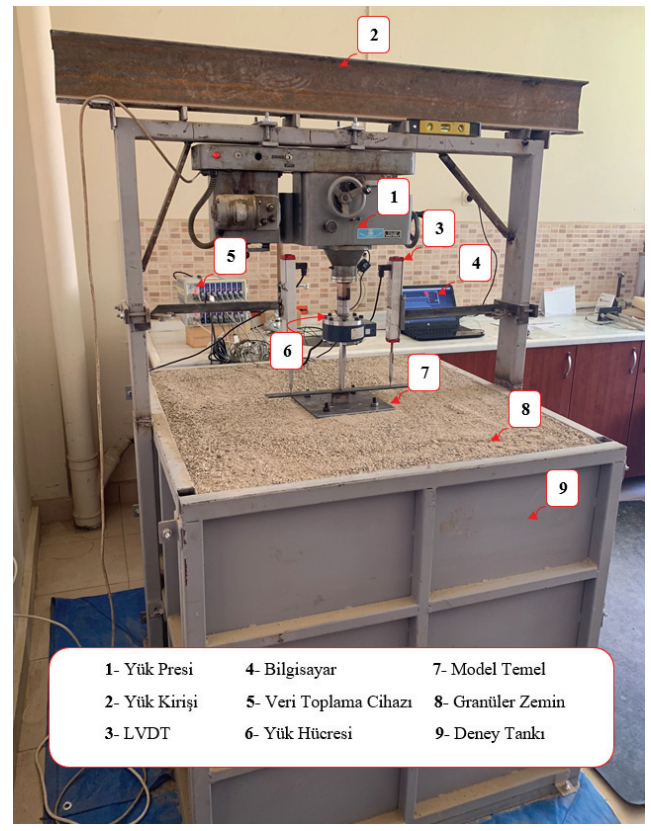

Şekil 1 - Deney düzeneğinin şemast 
Deneysel çalışmalarda kullanılan model kare radye temellerin bir kenarının uzunluğu 160 $\mathrm{mm}$ ve $240 \mathrm{~mm}$ olup, $6 \mathrm{~mm}$ kalınlığında çelik levhalardan üretilmiştir. Model temelin tabanında merkezi yükleme yapabilmek için başlık montajına uygun şeklinde delikler açılmıştır. Tam sürtünmeli ve pratikteki koşullara uygun olarak kalın bir zımpara kâğıdı temel tabanına yapıştırılmıştır. Şekil 2'de model radye temeller görülmektedir.

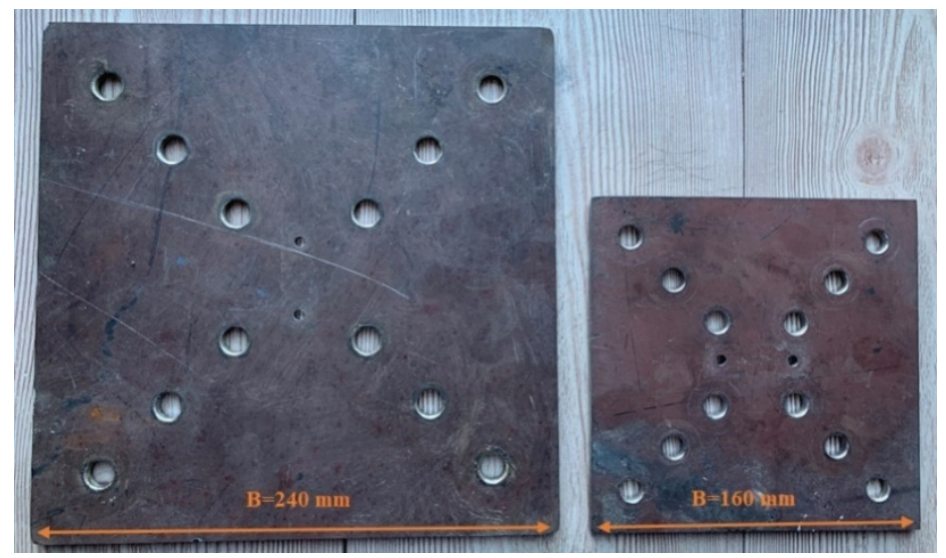

Şekil 2 - $B=240 \mathrm{~mm}$ ve $B=160 \mathrm{~mm}$ boyutunda model radye temeller

Laboratuvar deneylerinde kullanılacak model kazık parametreleri literatür taraması ve yapılan ön deneyler neticesinde kazık boyu $L=200 \mathrm{~mm}$ ve $300 \mathrm{~mm}$, kazık çapı $\mathrm{D}=20 \mathrm{~mm}$ ve $30 \mathrm{~mm}$ olacak şekilde belirlenmiştir. Yükleme deneylerinde kullanılacak kazıkları imal etmek için alüminyum kalıplar hazırlanmıştır. Model kazıklar ile kum zemin arasında gerçek zemin-beton sürtünme davranışını elde etmek amacıyla beton ve çelik çubuklar kullanılarak kompozit kazıklar hazırlanmıştır (Şekil 3).

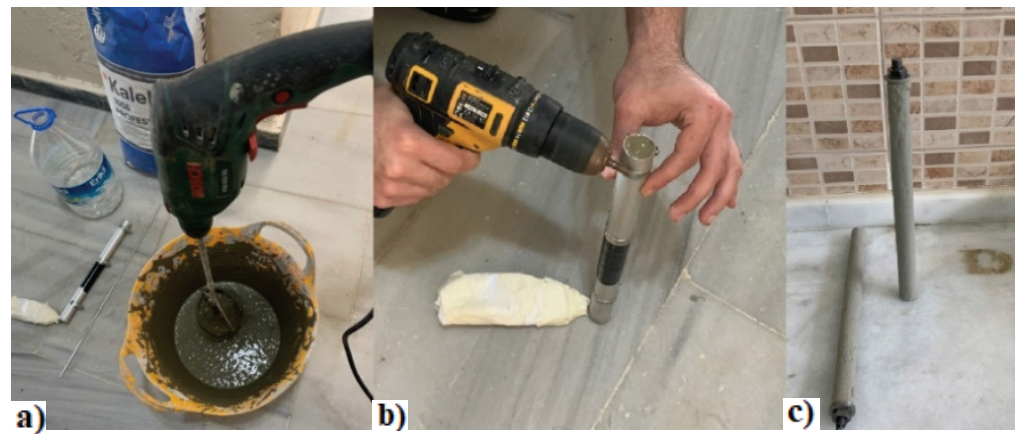

Şekil 3 - Kompozit model kazık imalatı a) betonun hazırlanması, b) alüminyum kalıba yerleştirilmesi, c) model kazıklar 
Deneysel çalışmalarda kullanılan model kazıklı radye temel, model kazıklar ve model radyenin bulonlar yardımıyla rijit olarak birleştirilmesi ile oluşturulmuştur. Şekil 4'de birleşim detayı gösterilmektedir.

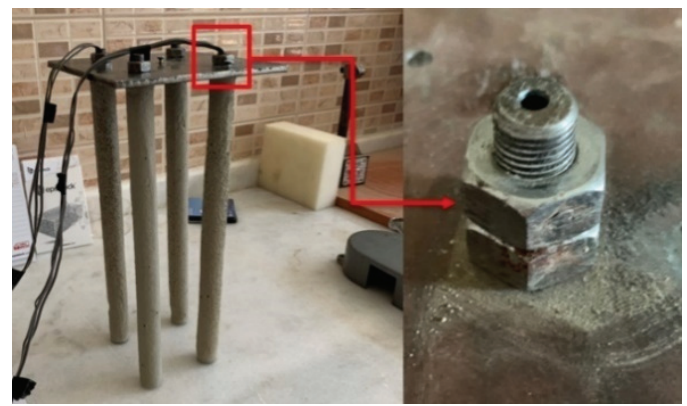

Şekil 4 - Model kazıklı radye temel ve rijit birleşim detayı

Deneylerde yükün uygulanması için, üç eksenli deney aletinin presi kullanılmıştır. Bu pres elektrik motoru sayesinde çeşitli hızlarda $(0,50 \mathrm{~mm} / \mathrm{dk}-1,50 \mathrm{~mm} / \mathrm{dk})$ sabit deformasyon uygulama ve elle kriko gibi kullanılma özelliklerine sahiptir. Pres düşey yükleme yapmak amacıyla deney tankına sabitlenmiş yük kirişine monte edilmiştir (Şekil 5a). Zemine uygulanan yüzey yüklerini ölçebilmek amacıyla kullanılan yöntemlerden biri de yükleme düzeneğinde yük hücresi kullanmaktır. Yük hücresi yardımıyla ölçüm almanın diğer yöntemlere göre en önemli avantajı, hassas ve zamana bağlı yükleme değeri ölçebilmesidir. Şekil 5b'de CAS Corporation firması tarafından üretilen $50 \mathrm{kN}$ kapasiteli LS-5T model yük hücresi görülmektedir. Presin ucuna düşey ve sabit olarak takılan bu yük hücresi, uygulanan yükü ölçmede kullanılmıştır. Deneylerden önce yük hücresi kalibre edilmiştir. Yük hücresine düşey olarak monte edilmiş ucu keskin yükleme bıçağı, model temeli yüklemek için kullanılmıştır. Deneysel çalışmalarda, model kazıklı radye temelin düşey yüklenmesi sonucu, temelde oluşan oturmaları ölçmek amacıyla, OPKON firması tarafından üretilen ve 150 mm'ye kadar deplasman değeri ölçebilen, LPS-150 model, Şekil 5c'de görülen, deplasman ölçerler (LVDT) kullanılmıştır. Bu deplasman ölçerler, \pm \% 0,05 (>200 mm), \pm \% 0,1 (130$200 \mathrm{~mm}), \pm \% 0,2(75-130 \mathrm{~mm}), \pm \% 0,5(<75 \mathrm{~mm})$ aralığında hassasiyete sahiptir. Yüklemeye maruz model kazıklı radye temelin oturması, temelin merkezine yakın ve eşit mesafedeki iki LVDT ile ölçülmüştür. Elde edilen oturma değerlerinin uyumlu olduğu görülmüş olup, ortalaması esas alınmıştır.

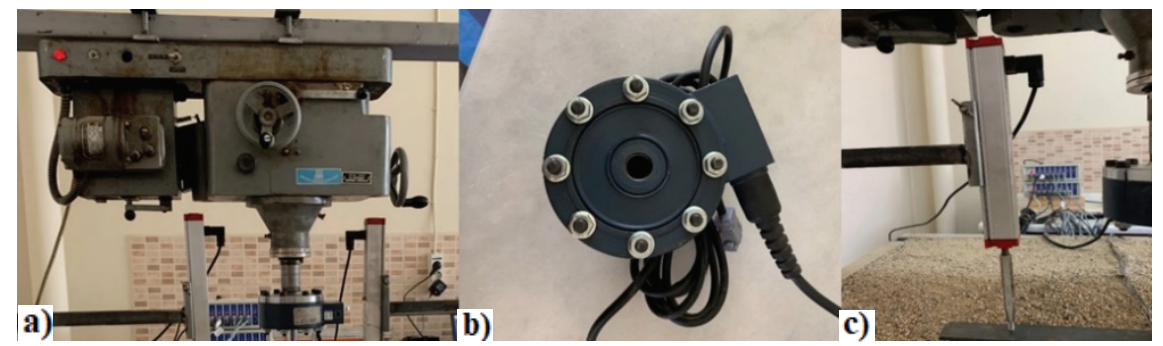

Şekil 5 - Yükleme düzeni a) yük presi, b) yük hücresi, c) LVDT 
Yük hücresi ve deplasman ölçerden elde edilen değerler, 8 kanal girişli veri toplama cihazı ve aygıt geçidi yardımıyla bilgisayara aktarılmıştır. Bu veriler CoDA Locomotive programı yardımıyla sayısal değerlere dönüştürülmüştür (Şekil 6).

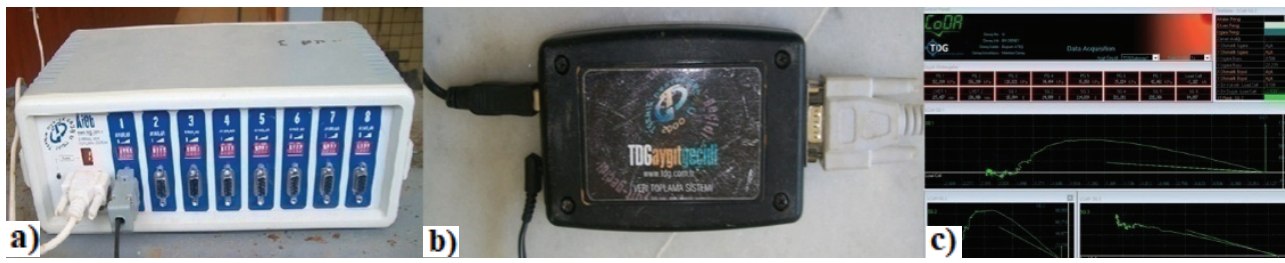

Şekil 6 - Ölçüm Cihazları a) veri toplama ünitesi, b) aygıt geçidi, c) CoDA Locomotive programıara yüzü

Deneylerde, İyidere ilçesinin (Rize) bitişiğindeki doğu sahilinden alınan kum kullanılmıştır. Kum, mevcut özelliklerini koruması ve gerçekçi bir zemin ortamı elde etmek amacıyla çok az yıkanmaya tabi tutulmuş olup doğal granülometrisi bozulmamaya çalışılmıştır. Deney kumunun, ASTM D-6913 [11] standartlarına göre granülometri eğrisi belirlenmiştir. Kumun granülometri eğrisinden, $\mathrm{D}_{10}=0,28 \mathrm{~mm}$ (efektif çap), $\mathrm{D}_{30}=0,73 \mathrm{~mm}$ ve $\mathrm{D}_{60}=1,71 \mathrm{~mm}$ olarak belirlenmiştir. $\mathrm{Bu}$ değerlerden üniformluluk katsayısı $C_{u}=6,11$ ve eğrilik katsayısı $C_{r}=1,11$ olarak hesaplanmıştır. Kumun dane çapları 0,1-5,0 mm arasında (iri-orta) olup, Birleştirilmiş Zemin Sınıflandırma Sistemine (USCS) göre iyi derecelenmiş kumdur (SW). Kumun, ilgili deneylerle belirlenmiş bazı özellikleri Tablo 1'de gösterilmiştir. Rölatif sıkılığın $\mathrm{D}_{\mathrm{r}}=0.30$ ve 0.70 olması için kumun kuru birim hacim ağırlığı aşağıdaki bağıntı yardımı ile hesaplanmıştır. Farklı rölatif sıkılıktaki deney kumuna ait kayma mukavemeti açısı değerleri kesme kutusu deneyi ile elde edilmiştir.

$D_{r}=\frac{\gamma_{k \max }}{\gamma_{k}}\left(\frac{\gamma_{k}-\gamma_{k \text { min }}}{\gamma_{k \text { max }}-\gamma_{k \text { min }}}\right)$

Kum, deney tankı içerisine tabakalar halinde ve iki farklı rölatif sıkılıkta $\left(D_{r}=\% 30\left(\gamma_{k}=15,80\right.\right.$ $\left.\mathrm{kN} / \mathrm{m}^{3}\right)$ ve $\left.\mathrm{D}_{\mathrm{r}}=\% 70\left(\gamma_{\mathrm{k}}=18,90 \mathrm{kN} / \mathrm{m}^{3}\right)\right)$ dinamik yöntemle sıkıştırılarak yerleştirilebilmesi için deney tankının iç yan yüzeyleri düşey yönde 5 'er $\mathrm{cm}^{\prime}$ lik ölçeklendirilmiştir. $\mathrm{D}_{\mathrm{r}}=\% 30$ rölatif sıkılık durumu için 5 cm'lik tabaka için gerekli kum ağırlığı, kumun sıkışmasını önlenmek amacıyla yakın mesafeden deney tankı içerisine dökülmüş ve sonrasında su terazisi vasıtasıyla zemine basınç uygulamadan yüzey düzeltilerek, kum zeminin tabaka boyunca homojen olarak yerleşmesi sağlanmıştır. $\mathrm{D}_{\mathrm{r}}=\%$ 70 rölatif sıkılık durumunda ise, zemin tabakası titreşim cihazı ile sıkıştırılmıştır. Söz konusu rölatif sıkılıklarda tabakaların yüksekliği tank yüzeyleri üzerinde bulunan ve tabaka sınırlarını belirten yatay çizgilere ile kontrol edilmiştir (Şekil 7a). Zemini tank içine istenilen rölatif sıkılıkta yerleştirme işlemi bittikten sonra model kazıklı radye temel $0,50 \mathrm{~mm} / \mathrm{dk}^{\prime}$ lık sabit bir penetrasyon hızıyla (Gök [16]; Bajad ve Sahu [17]; Nguyen vd. [18]) yerleştirilmiştir. Model kazıklı radye temeller kübik zemin haznesinde bulunan kum zemine itilerek yerleştirilmiştir. Model kazıklar kompozit malzemeden (beton ve çelik) imal edilmiş olup; oldukça rijittirler. Bu nedenle model kazıklarda, zemine itilmesi esnasında herhangi bir hasar oluşmamıştır. Model kazıklı temel zemine yerleştirilirken düzgünlüğü su terazileri yardımıyla her açıdan kontrol edilmiş 
ve radye temelin alt yüzeyi zemin ile temas ettiği an, yerleştirme işlemi durdurulmuş ve su terazisi vasıtasıyla yüzey kontrol edilmiştir. Deneye başlanmadan önce, düzeneğe ölçüm cihazları yerleştirilmiştir. Ölçüm cihazları, temel plakasının her iki tarafına yerleştirilen LVDT'ler ve eksenel yükleme cihazı ucuna yerleştirilen yük hücresinden oluşmaktadır (Şekil 7b). Ölçüm cihazlarının başlangıç değerleri sıfırlanıp, yük düşey yönde ve statik olarak uygulanmıştır. İstenilen deplasman değeri elde edilene kadar, $0.50 \mathrm{~mm} / \mathrm{dk}$ 'lık sabit yükleme hızı uygulanarak beklenilmiştir. Yapılan literatür çalışmalarında gördüğümüz üzere; model kazıklı radye temellerde yükleme kademelerinde lineer olmayan bir davranış görülmektedir. Tespit edilen düşey yük ve deplasman eğrilerinden, taşıma gücü tam manasıyla belirlenemediğinden, geoteknik mühendisliğinde bu tür durumlarda taşıma gücünün belirlenmesi için 4 yöntemin (0,1B Yöntemi ( $\mathrm{B}=$ radye temel genişliği) (Briaud ve Jeanjean [19]), Teğet Kesiştirme Yöntemi (Trautmann ve Kulhawy [20]), Log-Log Yöntemi (Debeer [21]) ve Hiperbolik Yöntem) kullanıldığı görülmektedir (Örnek, [22]; Lutenegger ve Adams [23]; Keskin [24]). Bu yöntemlerin her birinde farklı taşıma gücü değerleri elde edilebilmektedir. Bu yüzden, taşıma gücü değeri belirlenirken tek bir yöntemin belirlenmesi gerekmektedir. Bu çalışmada, düşey yük-oturma eğrilerinden belirgin bir taşıma gücü elde edilemediği için, diğer yöntemlere göre elde edilme yönünden daha pratik değerler veren 0,1B yöntemi esas alınmıştır. TDG firması tarafından üretilen Ai8b model numaralı veri toplama ünitesi ve RS-485 model numaralı aygıt geçidi yardımı ile veriler deney esnasında toplanmış ve CoDA Locomotive programı yardımıyla veriler sayısal değerlere dönüştürülmüştür. Elde edilen sayısal veriler ışı̆̆ında düşey yük-oturma eğrileri çizilmiştir (Şekil 7c). Ayrıca, sıkıştırılan zeminin homojenliği deney tamamlandıktan sonra deney tankına yerleştirilen numune kapları ile kontrol edilmiştir. Deneyler, her bir rölatif sıkılık için üç defa tekrarlanmış, sonuçlar kayıt altına alınmıştır.

Tablo 1 - Deney kumunun geoteknik özellikleri

\begin{tabular}{|c|c|c|}
\hline Özellik & Birim & Değer \\
\hline Dane özgül yoğunluğu, $G_{s}(\mathrm{ASTM}$ D854-14, [12]) & - & 2,64 \\
\hline Maksimum kuru birim hacim ağırlı̆̆ $1, \gamma_{k m a x} \quad$ (ASTM D4253-16, [13]) & $\mathrm{kN} / \mathrm{m}^{3}$ & 18,90 \\
\hline Minimum kuru birim hacim ağırlığ $1, \gamma_{k m i n} \quad$ (ASTM D4254-16, [14]) & $\mathrm{kN} / \mathrm{m}^{3}$ & 15,80 \\
\hline Efektif çap, $D_{10}$ & $\mathrm{~mm}$ & 0,28 \\
\hline$D_{30}$ & $\mathrm{~mm}$ & 0,73 \\
\hline$D_{60}$ & $\mathrm{~mm}$ & 1,71 \\
\hline Üniformluluk katsayısı, $\mathrm{C}_{u}$ & - & 6,11 \\
\hline Derecelenme katsayısı, $C_{r}$ & - & 1,11 \\
\hline Kayma mukavemeti açıs1, $\phi,\left(D_{r}=0,70\right) \quad($ ASTM D3080 / D3080M-11, [15]) & Derece & 44,00 \\
\hline Kayma mukavemeti açıs1, $\phi,\left(D_{r}=0,30\right) \quad($ ASTM D3080 / D3080M-11, [15]) & Derece & 37,00 \\
\hline
\end{tabular}




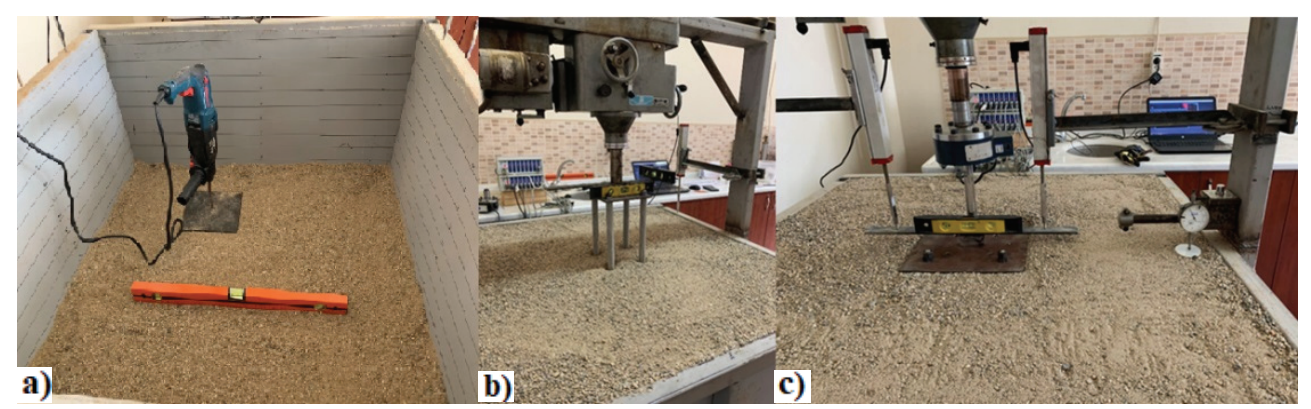

Şekil 7 - Bir deneyin yapılışı a) kumun yerleştirilmesi, b) kazıklı radye temelin zemine yerleştirilmesi, c) deneye başlangıç

\subsection{Deney Programı}

Kazıklar arası optimum mesafeyi belirlemek amacıyla $\mathrm{D}_{\mathrm{r}}=\% 30$ ve $\mathrm{D}_{\mathrm{r}}=\% 70$ rölatif sıkılığa sahip kum zemin içine gömülü kazıklı radye temellerde, Tablo 2'de belirtilen deneyler yapılmıştır. Deneysel çalışmalarda kazıklar arası mesafeyi belirlemek için özel radye temeller hazırlanmıştır. Hazırlanan model radye temellere model kazıklar eklenerek deneyler yapılmıştır. Böylece; kazıklar arası mesafenin (S) taşıma gücüne etkisi incelenmiştir.

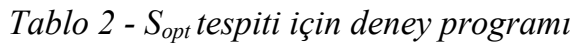

\begin{tabular}{|c|c|c|c|c|c|}
\hline Deney No & $\begin{array}{c}\text { Rölatif } \\
\text { Sıkılık } \\
\text { (D) }\end{array}$ & $\begin{array}{c}\text { Temel } \\
\text { Genişliği } \\
\text { (B, mm) }\end{array}$ & $\begin{array}{c}\text { Kazık } \\
\text { Çapı (D, } \\
\mathbf{~ m m ) ~}\end{array}$ & $\begin{array}{c}\text { Kazık } \\
\text { Boyu } \\
(\mathbf{L}, \mathbf{m m})\end{array}$ & $\begin{array}{c}\text { Kazıklar Arası } \\
\text { Mesafe (S/D) }\end{array}$ \\
\hline $\mathrm{T}_{1}, \mathrm{~T}_{2}, \mathrm{~T}_{3}, \mathrm{~T}_{4}, \mathrm{~T}_{5}$ & $\mathbf{0 3 0}$ & 160 & 20 & 200 & $2,3,4,5,6$ \\
\hline $\mathrm{T}_{6}, \mathrm{~T}_{7}, \mathrm{~T}_{8}, \mathrm{~T}_{9}, \mathrm{~T}_{10}$ & $\% 30$ & 160 & 20 & 300 & $2,3,4,5,6$ \\
\hline $\mathrm{T}_{11}, \mathrm{~T}_{12}, \mathrm{~T}_{13}, \mathrm{~T}_{14}, \mathrm{~T}_{15}$ & $\% 30$ & 240 & 30 & 200 & $2,3,4,5,6$ \\
\hline $\mathrm{T}_{16}, \mathrm{~T}_{17}, \mathrm{~T}_{18}, \mathrm{~T}_{19}, \mathrm{~T}_{20}$ & $\% 30$ & 240 & 30 & 300 & $2,3,4,5,6$ \\
\hline $\mathrm{T}_{21}, \mathrm{~T}_{22}, \mathrm{~T}_{23}, \mathrm{~T}_{24}, \mathrm{~T}_{25}$ & $\% 70$ & 160 & 20 & 200 & $2,3,4,5,6$ \\
\hline $\mathrm{T}_{26}, \mathrm{~T}_{27}, \mathrm{~T}_{28}, \mathrm{~T}_{29}, \mathrm{~T}_{30}$ & $\% 70$ & 160 & 20 & 300 & $2,3,4,5,6$ \\
\hline $\mathrm{T}_{31}, \mathrm{~T}_{32}, \mathrm{~T}_{33}, \mathrm{~T}_{34}, \mathrm{~T}_{35}$ & $\% 70$ & 240 & 30 & 200 & $2,3,4,5,6$ \\
\hline $\mathrm{T}_{36}, \mathrm{~T}_{37}, \mathrm{~T}_{38}, \mathrm{~T}_{39}, \mathrm{~T}_{40}$ & $\% 70$ & 240 & 30 & 300 & $2,3,4,5,6$ \\
\hline
\end{tabular}

\section{BULGULAR VE TARTIŞMA}

Deneysel çalışmada, model radye temel ve radye temelin merkezinden itibaren 2D, 3D, 4D, $5 \mathrm{D}$ ve $6 \mathrm{D}$ aralıklarla yerleştirilen kazıklar kullanılarak taşıma güçleri tespit edilmiştir. Şekil 8 'de görülen iki farklı kazık çapı, iki farklı kazık boyu ve iki farklı genişlikte radye temeller kullanılarak $D_{r}=\% 30$ ve $D_{r}=\% 70$ rölatif sıkılığa sahip kum zeminde model deneyler 
yapılmıştır. Model radye genişlikleri ve kazık sayısı, çap ve boyları, çalışma kapsamında yapılan geniş bir literatür çalışması sonucunda seçilmiştir. Deneyler neticesinde kazıklı radye temellerde, kazıklar arası optimum mesafenin $\left(\mathrm{S}_{\mathrm{opt}}\right)$ belirlenmesi hedeflenmiştir.
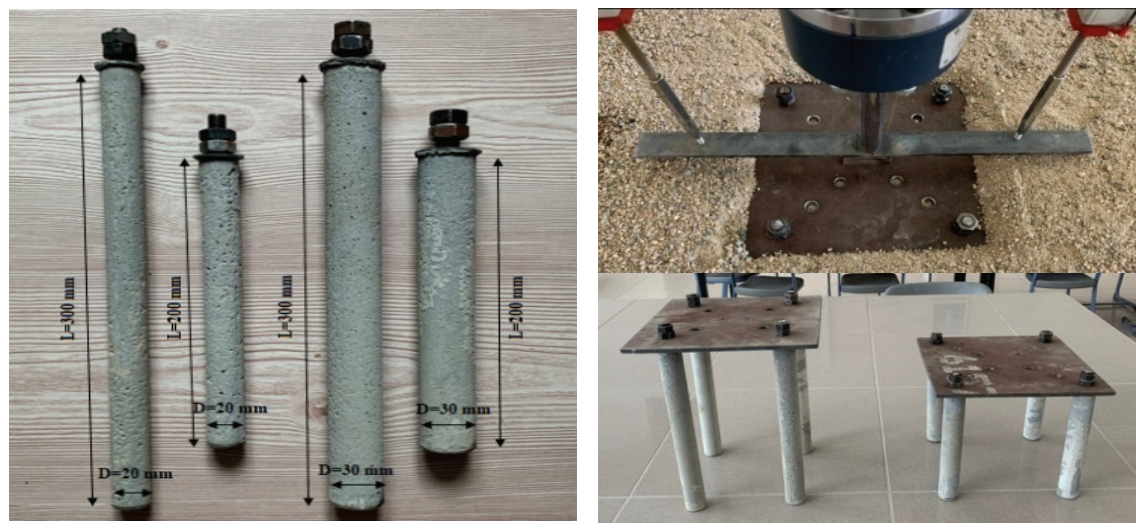

Şekil 8 - Model kazıklı radye temel

Şekil 9a ve 9b'de $D=20 \mathrm{~mm}, \mathrm{~L}=200$ ve $300 \mathrm{~mm}, \mathrm{D}_{\mathrm{r}}=\% 30$ ve $\mathrm{B}=160 \mathrm{~mm}$ durumu için elde edilen yük-oturma eğriler görülmektedir. Radye temel ile kazıklı radye temelin yük-oturma ilişkisi arasında belirgin bir farklılık bulunmakta, kazıkların kullanılması yük-oturma ilişkisi açısından temel sisteminin rijitliğinde önemli bir artışa sebep olmaktadır. Kazık aralığının artışıyla birlikte model kazıklı radye temelde belirli oturmalara karşı gelen yüklerde 4D kazık aralığına kadar artış meydana gelmekte, yani yük-oturma eğrisinin eğimi artmaktadır. Benzer şekilde kazık uzunluğunun artmasıyla da kazıklı radye temelin taşıdığı belirli oturmalara karşı gelen yüklerde 4D kazık aralığına kadar artış meydana gelmekte, bu kazık aralığından itibaren $(5 \mathrm{D}, 6 \mathrm{D})$ yüklerde çok az miktarda bir azalma oluşmaktadır.

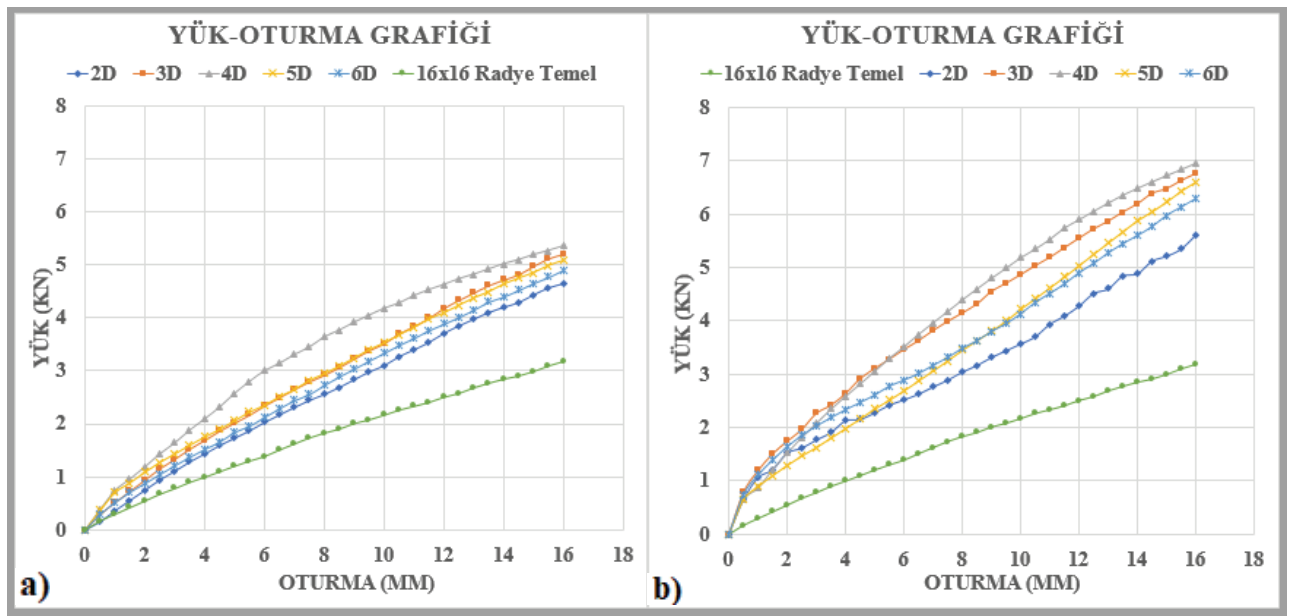

Şekil 9 - Yük-oturma ĕgrileri a) $\left.D_{r}=\% 30, D=20 \mathrm{~mm}, B=160 \mathrm{~mm} \mathrm{~L}=200 \mathrm{~mm} \mathrm{~b}\right) D_{r}=\% 30$, $D=20 \mathrm{~mm}, B=160 \mathrm{~mm}, L=300 \mathrm{~mm}$ 
Şekil 10.a ve Şekil 10.b'de D=20 mm, L=200 ve $300 \mathrm{~mm}, \mathrm{Dr}=\% 70$ ve $B=160 \mathrm{~mm}$ durumu için elde edilen yük-oturma eğrileri görülmektedir. Radye temel ile kazıklı radye temelin yük-oturma ilişkisi arasında belirgin farklılık, düşük rölatif sıkılıkta olduğu gibi yüksek rölatif sıkılıkta da bulunmaktadır. Kazıkların kullanılması ve rölatif sıkılığın artması yükoturma ilişkisi açısından temel sisteminin rijitliğinde önemli bir artışa sebep olmuştur. Yükoturma eğrisinde belirgin iki farklı eğimin olduğu iki bölge ortaya çıkmış ve kazık uzunluğunun artmasıyla birinci bölgede belirli oturmalara karşı gelen yüklerde önemli artışlar oluşmuştur. Kazık aralığının artışıyla birlikte, model kazıklı radye temelde belirli oturmalara karşı gelen yüklerde 4D kazık aralığına kadar artış meydana gelmekte, yani yükoturma eğrisinin eğimi artmaktadır. Benzer şekilde kazık uzunluğunun artmasıyla da kazıklı radye temelin taşıdığı belirli oturmalara karşı gelen yüklerde 4D kazık aralığına kadar artış meydana gelmekte, bu kazık aralığından itibaren $(5 \mathrm{D}, 6 \mathrm{D})$ yüklerde çok az miktarda bir azalma oluşmaktadır.

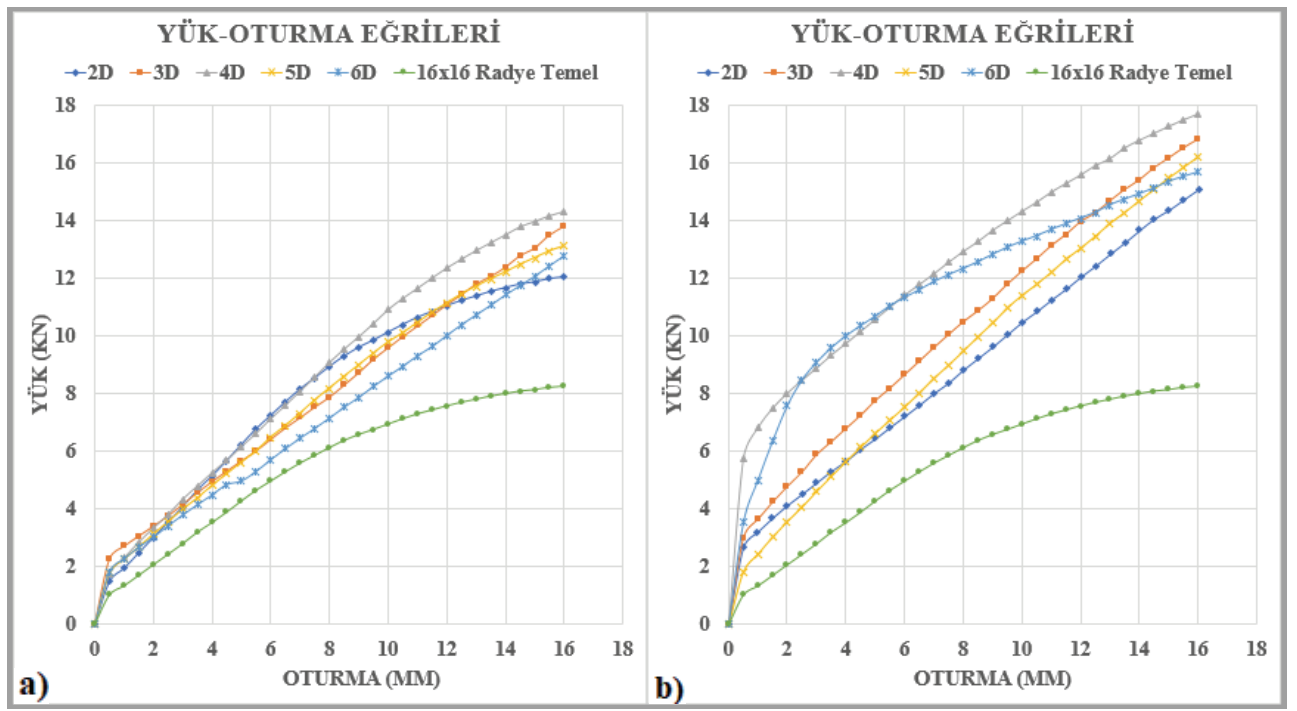

Şekil 10 - Yük-oturma ĕgrileri a) $D_{r}=\% 70, D=20 \mathrm{~mm}, B=160 \mathrm{~mm}, L=200 \mathrm{~mm}$ b) $D_{r}=\% 70$, $D=20 \mathrm{~mm}, B=160 \mathrm{~mm}, L=300 \mathrm{~mm}$

Farklı kazık aralıklarına sahip model kazıklı radye temellerin $(D=20 \mathrm{~mm}, \mathrm{~B}=160)$ kazık aralığına bağlı olarak nihai taşıma güçleri toplu olarak Şekil 11'de görülmektedir. $D=20 \mathrm{~mm}$ durumu için; kazıklı radye temeldeki, kazıklar arası mesafe 4D aralığına kadar arttırıldıkça, farklı rölatif sıkılıklarda taşıma gücünde kayda değer bir artış meydana gelmiştir. Ancak kazıklar arası mesafe 4D'den büyük olduğunda (5D ve $6 \mathrm{D})$ taşıma gücünde bir miktar azalma meydana gelmektedir (Şekil 11). $\mathrm{D}_{\mathrm{r}}=\% 30$ ve $\mathrm{D}_{\mathrm{r}}=\% \mathbf{0}$ \% rölatif sıkılık değerlerinde; $\mathrm{D}=20 \mathrm{~mm}, \mathrm{~L}=200 \mathrm{~mm}$ için kazıklar arası mesafe 4D alındığı durumda, radye temele göre taşıma gücünde sırasıyla yaklaşık $\% 68-74$ oranında artış gözlemlenmektedir. $\mathrm{D}_{\mathrm{r}}=\% 30$ ve $\mathrm{Dr}=\% 70$ rölatif sıkılık değerlerinde, kazık boyunun $\mathrm{L}=300 \mathrm{~mm}$ olması durumunda, radye temele göre taşıma gücünde sırasıyla yaklaşı \% 118 -114 oranında artış olduğu gözlenmiştir. 
Kum Zeminlerdeki Kazıklı Radye Temellerin Optimum Kazık Aralı̆̆ının Deneysel ...

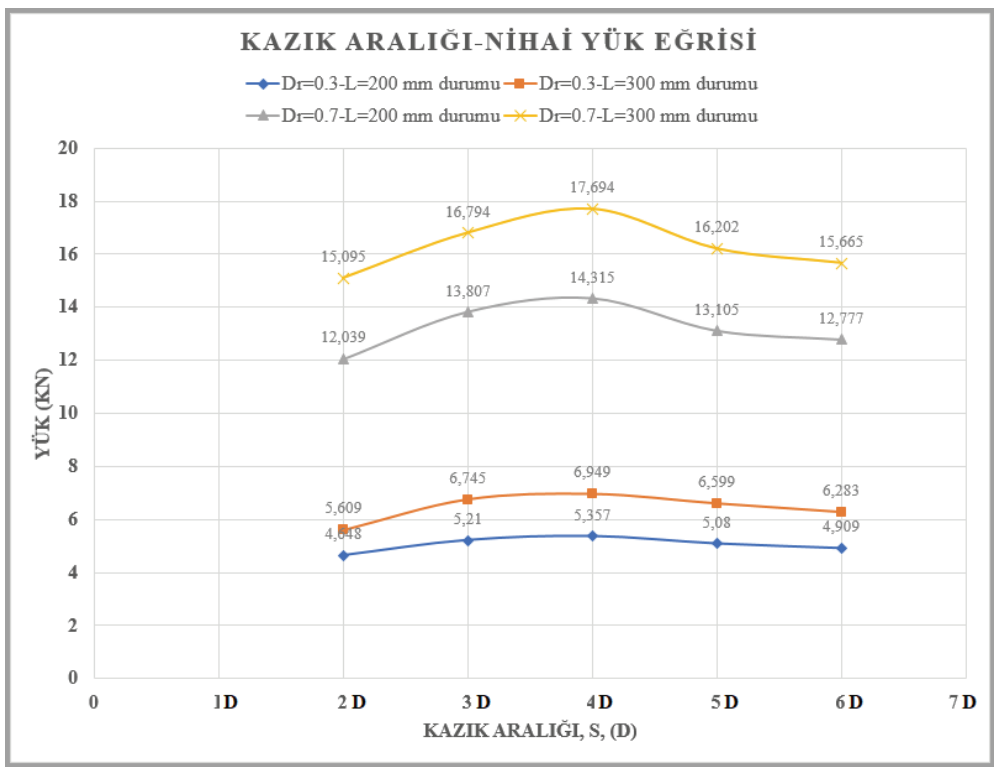

Şekil 11 - Kazıklı radye temellerde $B=160 \mathrm{~mm}, D=20 \mathrm{~mm}$ için kazık aralı̆̆ına bağlı nihai yük ĕgrileri

Şekil 12.a ve Şekil 12.b'de $D=30 \mathrm{~mm}, \mathrm{~L}=200$ ve $300 \mathrm{~mm}, \mathrm{D}_{\mathrm{r}}=\% 30$ ve $\mathrm{B}=240 \mathrm{~mm}$ durumları için elde edilen yük-oturma eğriler görülmektedir. $\mathrm{D}=20 \mathrm{~mm}$ 'lik kazıklarda olduğu gibi, radye temel ile kazıklı radye temelin yük-oturma ilişkisi arasında belirgin bir farklılık bulunmakta, kazıkların kullanılması yük-oturma ilişkisi açısından temel sisteminin rijitliğinde önemli bir artışa sebep olmaktadır. Kazık aralığının artışıyla birlikte model kazıklı radye temelde belirli oturmalara karşı gelen yüklerde 4D kazık aralığına kadar artış meydana gelmektedir.

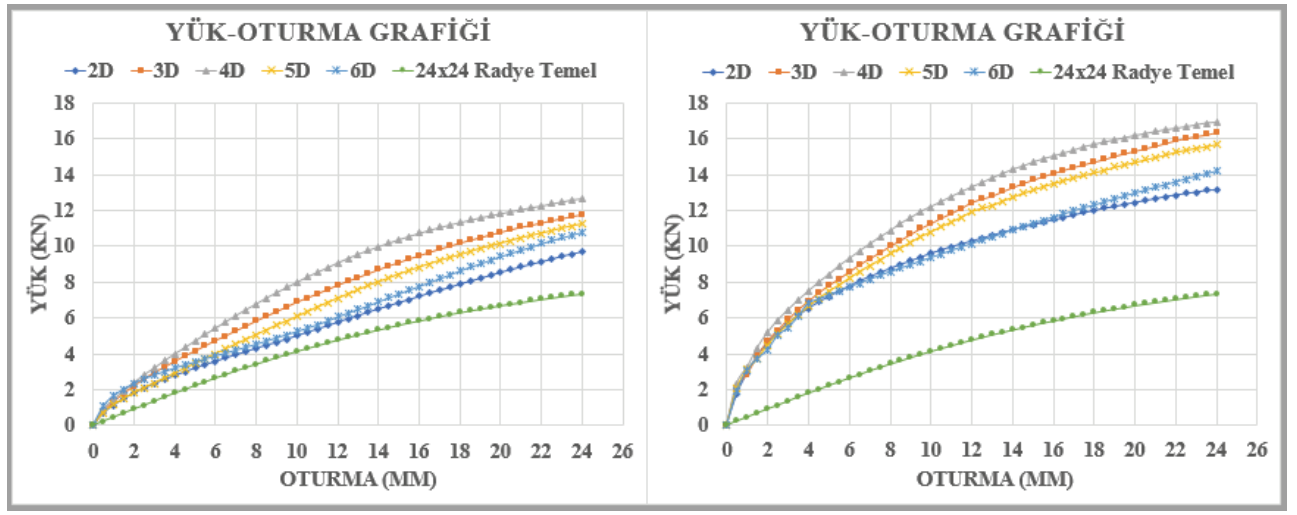

Şekil 12 - Yük-oturma eğrileri a) $\left.D_{r}=\% 30, D=30 \mathrm{~mm}, B=240 \mathrm{~mm} \mathrm{~L}=200 \mathrm{~mm} \mathrm{~b}\right) D_{r}=\% 30$, $D=30 \mathrm{~mm}, B=240 \mathrm{~mm}, L=300 \mathrm{~mm}$ 
Şekil 13.a ve Şekil 13.b'de $D=30 \mathrm{~mm}, \mathrm{~L}=200$ ve $300 \mathrm{~mm}, \mathrm{D}_{\mathrm{r}}=\% 70$ ve $\mathrm{B}=240 \mathrm{~mm}$ durumları için elde edilen yük-oturma eğrileri görülmektedir. Zeminin yüksek rölatif sıkılığa sahip olduğu bu deneylerde, düşük yük mertebelerinde radye temel ile kazıklı radye temelin yükoturma ilişkisi arasında ihmal edilebilir farklılıklar mevcuttur.Yükün artmasıyla birlikte, kazıklar etkinliğini göstermekte ve kazıklı radye temelin rijitliği radye temele göre oldukça yüksek olmaktadır. Kazık aralığının 4D’ye kadar artmasıyla kazıklı radye temelin rijitliği artmakta, bundan büyük kazık aralıklarında (5D, 6D) kazık-radye sisteminin rijitliğinde azalma meydan gelmektedir. Yani aynı yüklerde, daha büyük oturmalar oluşmaktadır.

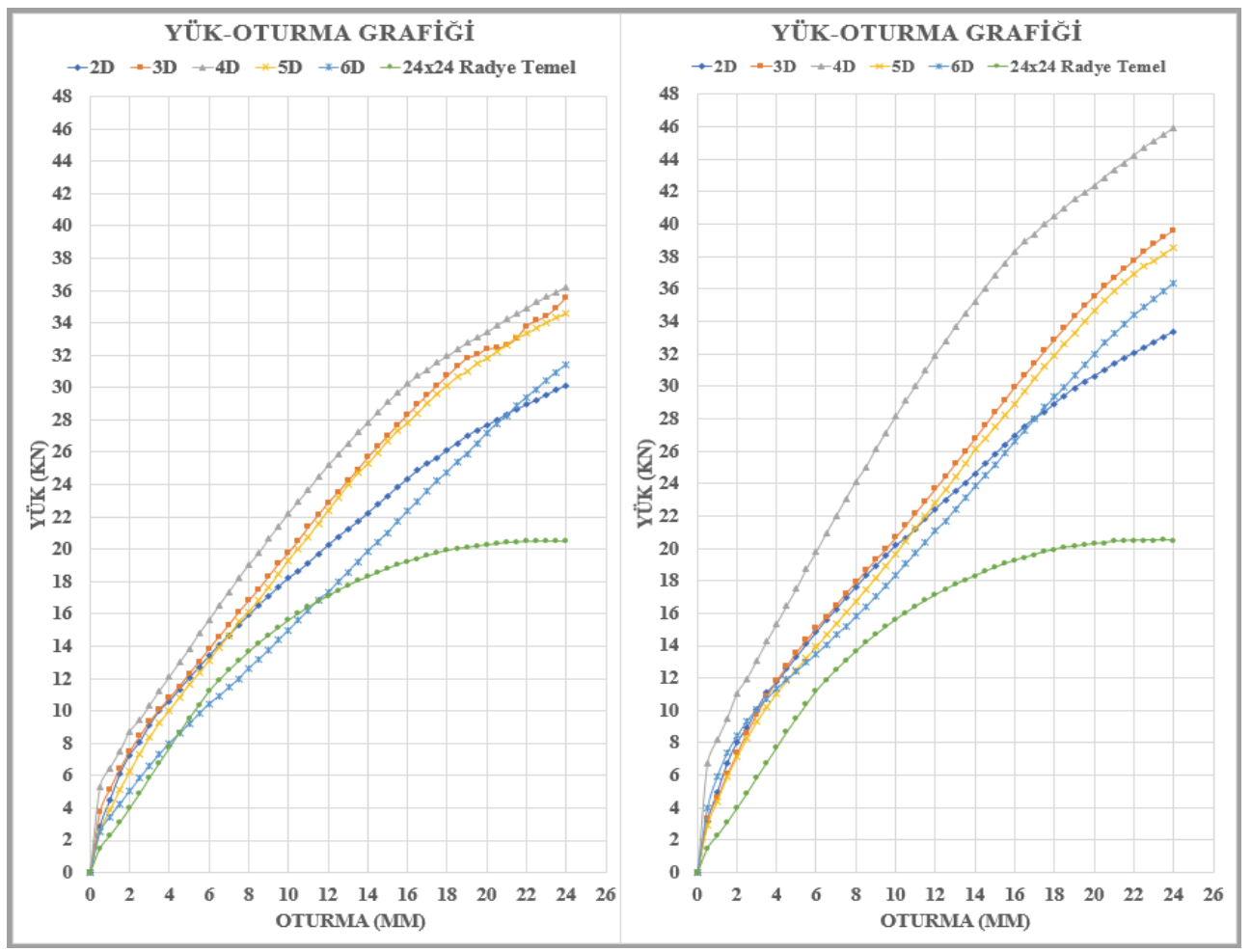

Şekil 13 - Yük-oturma ĕgrileri a) $D_{r}=\% 70, D=30 \mathrm{~mm}, B=240 \mathrm{~mm}, L=200 \mathrm{~mm}$ b) $D_{r}=\% 70$, $D=30 \mathrm{~mm}, B=240 \mathrm{~mm}, L=300 \mathrm{~mm}$

Farklı kazık aralıklarına sahip model kazıklı radye temellerin $(\mathrm{D}=30 \mathrm{~mm}, \mathrm{~B}=240 \mathrm{~mm})$ kazık aralığına bağlı nihai taşıma güçleri toplu olarak Şekil 14'de görülmektedir. Model kazıklı radye temeldeki kazık çapının \%50 arttırılmasıyla $(\mathrm{D}=30 \mathrm{~mm})$ birlikte, kazıklar arası mesafe 4D aralığına kadar arttırıldıkça farklı rölatif sıkılıklarda taşıma gücünde gözle görülür bir artış meydana getirmiştir. Ancak 4D'den büyük kazık aralıklarında (5D ve 6D) taşıma gücünde azalma meydana geldiği görülmüştür. $\mathrm{D}_{\mathrm{r}}=\% 30$ ve $\mathrm{D}_{\mathrm{r}}=\% 70$ rölatif sıkılık değerlerinde; $\mathrm{D}=30 \mathrm{~mm}, \mathrm{~L}=200 \mathrm{~mm}$ için kazıklar arası mesafe 4D alındığı durumda, radye temele göre taşıma gücünde sırasıyla yaklaşık \%42-77 oranında artış gözlemlenmektedir. Ayrıca; $D_{r}=\% 30$ ve $D_{r}=\% 70$ rölatif sıkılık değerlerinde kazık boyunun $L=300 \mathrm{~mm}(\% 50$ 
arttırılması) olması durumunda ise radye temele göre taşıma gücünde sırasıyla yaklaşık \%129-124 oranında artış olduğu gözlenmiştir.

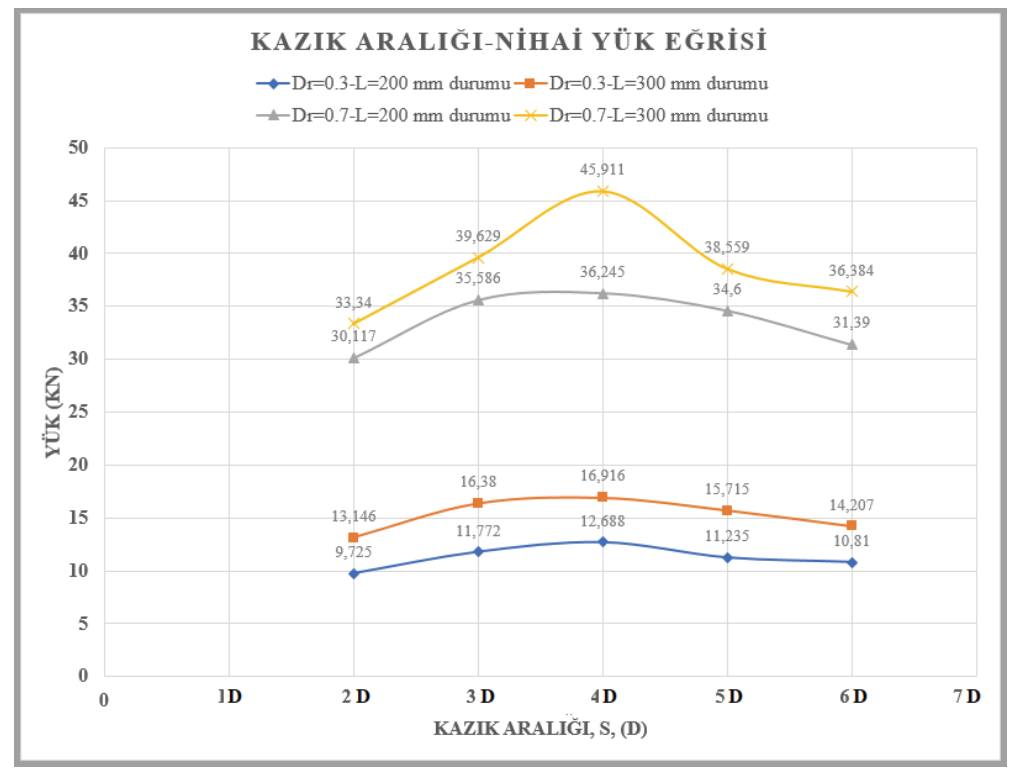

Şekil 14 - Kazıklı radye temellerde B=240mm, D=30 mm için kazık aralı̆̆ına bağlı nihai yük ĕgrileri

Şekil 15'den görüldüğü gibi, literatürde önerilen optimum kazık aralıklarının çok geniş (2,5D-12D) olması, tasarım yapılırken, kazıklar arası mesafenin belirlenmesinde karmaşaya yol açmaktadır. Literatürdeki bu değerlerin geniş aralıkta değişkenlik göstermesinin asıl sebebi söz konusu çalışmaların, farklı kazık çapları, farklı kazık boyları, farklı radye genişlikleri ve farklı zemin ortamı gibi kazıklar arası mesafeyi etkileyen önemli parametrelerin farklılığından kaynaklanmaktadır. Bu çalışmalarda önerilen optimum kazık aralıklarının ortalaması yaklaşık 4D’ye eşittir.

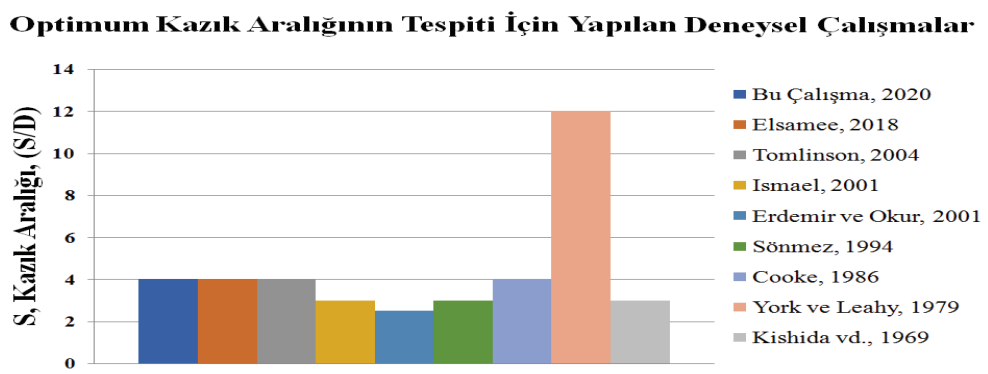

Şekil 15 - Optimum kazık aralı̆̆ının tespiti için yapılan çalışmaların karşılaştırılması 


\section{SONUÇLAR}

$\mathrm{Bu}$ çalışmada, kazıklı radye temellerin tasarım değişkenlerinin taşıma gücü ve yük-oturma ilişskisi üzerine etkisinin araştırılması amaçlanmıştır.Bu amaca yönelik olarak bir model deney düzeneği oluşturulmuş, radye ve kazıklı radye durumlarını içerecek şekilde yükleme deneyleri yapılmıştır.Bu deneylerle kazıklar arası optimum mesafeye; kazık boyu, kazık çapı ve rölatif sıkılık gibi tasarım parametrelerinin etkisi incelenmiştir. Yapılan deneysel çalışmalar sonunda elde edilen başlıca sonuçlar aşağıda sıralanmıştır:

- Çeşitli boyutlardaki model kazıklı radye temellerle, farklı rölatif sıkılıktaki (\%30 ve \%70)kum zeminde yapılan taşıma gücü deneylerinde, kazık aralığının (S) kazık çapının (D) dört katına kadar artmasıyla taşıma gücünde önemli artışlar oluşmuştur. Bu aralıktan sonra kazık aralığındaki artış, taşıma gücünde bir miktar azalmaya sebep olmuştur. Yapılan tüm deneysel çalışmalarda, kum zemine oturan kazıklı radye temellerde optimum kazık aralığı, kazık çapının dört katı $\left(\mathrm{S}_{\mathrm{opt}}=4 \mathrm{D}\right)$ olarak belirlenmiştir.

- Optimum kazık aralığının; kazık uzunluğu (L), kazık çapı (D) ve rölatif sıkılıktan ( $\left.D_{\mathrm{r}}\right)$ önemli derece etkilenmediğini görülmüş̧ür.

- Gevşek kum durumunda kazıklı radye temellerde kazıklar, radye temele göre taşıma gücünde \%42-129 oranlarında artışa sebep olmaktadır. Benzer şekilde, sıkı kum zeminde kazıklı radye temellerdeki kazıklar, taşıma gücünde radye temele göre \%74-124 arasında artışa sebep olmaktadır. Yani kazıklı radye temellerde, kazıklar taşıma gücünde önemli artışa sebep olmaktadır ve taşıma gücü artış oranı üzerinde, kazık uzunluğu (L), kazık çapı (D) ve rölatif sıkılık $\left(D_{r}\right)$ etkilidir.

\section{Semboller}

\begin{tabular}{|c|c|}
\hline $\mathrm{B}$ & : Model radye temel genişliği \\
\hline $\mathrm{C}_{\mathrm{r}}$ & : Derecelenme katsayıs1 \\
\hline $\mathrm{C}_{\mathrm{u}}$ & : Üniformluluk katsayısı \\
\hline $\mathrm{D}$ & : Kazık çapı \\
\hline $\mathrm{D}_{\mathrm{r}}$ & : Rölatif sık1lık \\
\hline $\mathrm{D}_{10}$ & : Efektif çap \\
\hline $\mathrm{D}_{30}$ & : Dane çapı dağılımı eğrisinde \%30’a karşılık gelen çap \\
\hline $\mathrm{D}_{60}$ & : Dane çapı dağılımı eğrisinde \%60’a karşılık gelen çap \\
\hline $\mathrm{e}$ & : Boşluk oranı \\
\hline $\mathrm{E}$ & : Elastisite modülü \\
\hline $\mathrm{G}_{\mathrm{s}}$ & : Dane özgül yoğunluğu \\
\hline $\mathrm{q}_{\text {sinir }}$ & :Sınır taşıma gücü \\
\hline LVDT & Lineer değișken diferansiyel transformatör \\
\hline
\end{tabular}




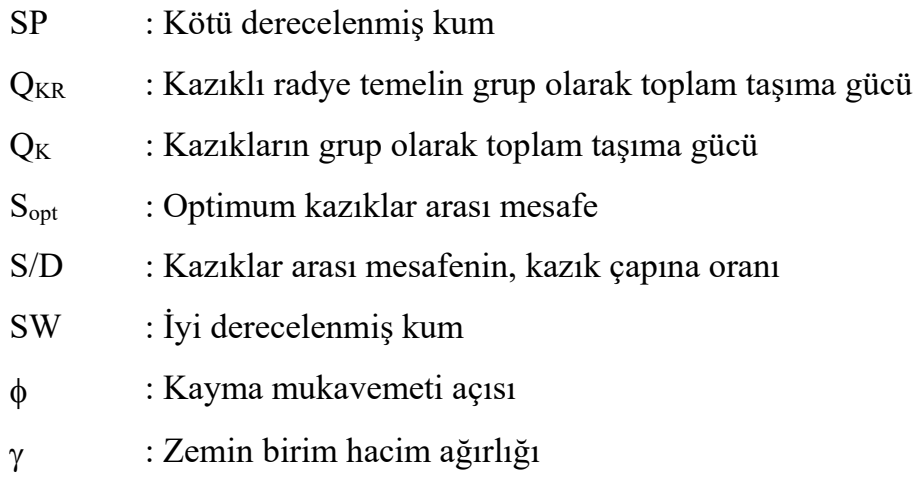

\section{Kaynaklar}

[1] Kishida, H., Matsushita K. ve Sakamoto I., Soil-StructureInteraction of the Elevator Tower and Concrete Footings, Proceedings of the4th World Conference on Earthquake Engineering, 3, Santiago de Chile,101-115, 1969.

[2] Cooke, R.,W., Piled Raft Foundations on Stiff Clays-A Contribution toDesign Philosophy, Géotechnique, 36(2), 169-203, 1986.

[3] Whitaker, T., Some Experiments on Model Piled Foundations in Clay, $6^{\text {th }}$ International Congress of International Association of Bridge StructureEngineering, Stockholm, Sweden, 124-139, 1961.

[4] Sönmez, D., D., Orta sıkılıktaki kumdaki kazık gruplarının negatifsürtünmesi ile ilgili bir model çalışma, Yüksek Lisans Tezi, Orta DoğuTeknik Üniversitesi, Fen Bilimleri Enstitüsü, Ankara, 89, 1994.

[5] Tomlinson, M., J., Pile Design and Construction Practice, Chapman andHall, London, UK, 2004.

[6] York, D., L.,ve Leahy, R., J., Experiences with Heave and Relaxation ofEnd Bearing Piles, Associated Pile and Fitting Corp, Pile Talk Seminer, NewYork, 73-85, 1979.

[7] Ismael N., F., Axial Load Tests on Pile and Pile Group in Cemented Sands,Journal of Geotechnical and Geoenvironmental Engineering, 42(3), 767-773, 2001.

[8] Tomlinson M. J., Pile Design and Construction Practice, E\&FN Spon, London, 1994.

[9] Özkan, M.T., Sağlamer, A., Kazıklı Temeller, Dünya İnşaat Dergisi, 131/7, 34-38, 1995.

[10] Elsamee, W. A., Effect of Pile Spacing On Ultimate Capacity and Load Shearing for Piled Raft Foundation, International Journal of Applied Engineering Research ISSN 0973-4562, 13, 8, 2018.

[11] A.S.T.M., Standard Test Methods for Particle-Size Distribution (Gradation) of Soils Using Sieve Analysis, D-6913, American Society for Testing and Materials, West Conshohocken, 34, 2017. 
[12] A.S.T.M., Standard Test Methods for Specific Gravity of Soil Solids by Water Pycnometer, D-854, American Society for Testing and Materials, West Conshohocken, 8, 2006.

[13] ASTM D4253-16, Standard Test Methods for Maximum Index Density and Unit Weight of Soils Using a Vibratory Table, ASTM International, West Conshohocken, PA, www.astm.org, 2016.

[14] ASTM D4253-16, Standard Test Methods for Maximum Index Density and Unit Weight of Soils Using a Vibratory Table, ASTM International, West Conshohocken, PA, www.astm.org, 2016.

[15] ASTM D3080 / D3080M-11, Standard Test Method for Direct Shear Test of Soils Under Consolidated Drained Conditions, ASTM International, West Conshohocken, PA, www.astm.org, 2011.

[16] Gök, S., Kazıklı Radye Temellerin Analizi. Doktora Tezi, İstanbul TeknikÜniversitesi, Fen Bilimleri Enstitüsü, İstanbul, 101, 2007.

[17] Bajad, S. P. ve Sahu, R. B., An Experimental Study on the Behaviour ofVertically Loaded Piled Raft on Soft Clay, The 12th International Conferenceof International Association for Computer Methods and Advances inGeomechanics (IACMAG), India, 84-91, 2008.

[18] Nguyen, D. D. C., JO, S. B. and Kim, D. S., Design method of piled-raft foundations under vertical load considering interaction effects, Computersand Geotechnics, 47, 1627, 2013.

[19] Briaud, J.L. ve Jeanjean, P., Load settlement curve method for spread footings on sand,Vertical and Horizontal Deformations of Foundations andEmbankments, ASCE, 2, 1774-1804, 1994.

[20] Trautmann, C.H. ve Kulhawy, F.H., Uplift load-displacement behavior of spread foundations,Journal of Geotechnical Engineering, ASCE, 114, 2, 168-183, 1998.

[21] Debeer, E.E., Experimental determination of the shape factors and the bearing capacity factors of sand,Geotechnique, 20, 4,387-411, 1970.

[22] Örnek, M, Yumuşak Kil Zeminlerin Geogrid Donatı ile Güçlendirilmesi, Doktora Tezi, Çukurova Üniversitesi, Fen Bilimleri Enstitüsü, Adana, 318, 2009.

[23] Lutenegger, A.J. ve Adams, M.T., Bearing Capacity of Footings on Compacted Sand. Proceedings of the 4th International Conference on Case Histories in Geotechnical Engineering, 1216-1224, 1998.

[24] Keskin, M. S., Güçlendirilmiş Kumlu Şevlere Oturan Yüzeysel Temellerin Deneysel ve Teorik . Doktora Tezi, Çukurova Üniversitesi, Fen BilimleriEnstitüsü, Adana, 2009. 
